\title{
Effect of sub-lethal doses of imidacloprid on histological and biochemical parameters in female albino mice
}

\author{
Ajay Kumar ${ }^{1}$, Monika Tomar ${ }^{1}$, Sudhir Kumar Kataria ${ }^{2}$ \\ ${ }^{1}$ Maharshi Dayanand University, Rohtak, Haryana, India \\ ${ }^{2}$ Regional Institute of Education (NCERT), Ajmer, Rajasthan, India
}

\begin{abstract}
Imidacloprid insecticide was selected to study its effects on biochemical (total protein, acetylcholinestrase and nucleic acids) and histological (liver) parameters in female albino mice at orally administered doses of 25, 50 and $75 \% \mathrm{LD}_{50}$ Imidacloprid and $40 \mathrm{mg} / \mathrm{kg}$ bw Cyclophosphamide $(C P)$ and distilled water $(D W)$. Significant decrease in total protein $(P<0.01)$, acetylcholinestrase $(P<0.001)$ and DNA $(P<0.05)$ were observed with increase in doses as compared to control group whereas slight dose dependent significant increase was noticed for RNA $(P<0.01)$. The change noticed in DNA and RNA for low dose of Imidacloprid was insignificant. The maximum damage with $C P$ and $75 \% L D_{50}$ Imidacloprid dose were noticed. Liver of mice showed degeneration of hepatocytes, dilation of sinusoids, irregular hepatic cords arrangement, leucocytes infiltration, necrosis and hemorrhages. This reveals biochemical and histotoxicity induction by Imidacloprid so awareness about its judicious use by farmers/users is of pivotal importance to have safe next generations.
\end{abstract}

Keywords: Cyclophosphamide, female albino mice, Imidacloprid, neonicotinoids, total protein

\section{Introduction}

Pesticides are extensively used all over the world since the human realization to control the harmful effects of pests on different crops and food stuffs to cater maximum yield of growing human population. Neonicotinoids are widely used plant systemic insecticides developed in the last some decades [1]. Imidacloprid was launched in 1991 for the first time by Bayer Crop-Science [2-4]. Imidacloprid is an extensively used for crop protection worldwide from the last decade due to its low soil persistence and high insecticidal activity at very low application rate. The selective toxicity of Imidacloprid to insects and not to mammals reported to be due to differences in the structure and binding affinity at the nicotinic acetylcholine receptor [5-7]. Imidacloprid exposure leads to block a type of neuronal pathway which causes the accumulation of acetylcholine which leads to paralysis and eventually death of the insect pests [8].

The indiscriminate and improportionate use of pesticides may lead to their residues in food chain which may exert their harmful effects in target and non target organisms [9-10]. Imidacloprid has been classified as both a toxicity Class II and Class III pesticide on a scale of I to IV with I being the highest toxicity class [11]. It has been reported that in acute poisoning cases in humans following ingestion of an insecticide formulation containing approximately 10\% Imidacloprid [12] and Imidacloprid intoxication resulted in fatalities [13-16]. Various studies have shown that environmental contaminants can alter biochemical system in fish [17-19], snails [20] and rat [21]. Therefore, the present study was carried out to investigate the effect of different doses of Imidacloprid on biochemical parameters like total protein, acetylcholiestrase, nucleic acids and histology of liver in female mice.

\section{Materials and Methods}

Swiss albino female mice (Mus musculus) a rodent species, was selected as experimental animal and were obtained from Lala Lajpat Rai University of Veterinary Science, Hisar, Haryana, India. Mice were kept in cages for at least 5 days prior to dosing for acclimatization to the laboratory conditions in a wire topped polypropylene cage with paddy husk bedding. The temperature in the experimental animal room was maintained at $22^{\circ} \mathrm{C} \pm 3^{\circ} \mathrm{C}$ with relative humidity $50--60 \%$. Artificial lighting sequence i.e. $12 \mathrm{hrs} \mathrm{light} \mathrm{and}$ 12 hours dark was maintained. The control and reared animals were given food in pellet form and water $a d$ libitum. The mice were randomly selected, marked by tail painting to permit individual identification. The experiments were approved by the Institutional Animal Ethics Committee, Maharshi Dayanand University, Rohtak, and Haryana, India.

At the time of dosing each mouse was between $20-25 \mathrm{~g}$ b.w. and 8 to 12 weeks old. After acclimatization animals were divided into five groups consisting of 5 mice each. Group 1 served as control, groups 2 - 4 were treated with imidacloprid doses at the rate of $37.5,75$ and $112.5 \mathrm{mg} / \mathrm{kg}$ b.w. and group 5 was treated with $40 \mathrm{mg} / \mathrm{kg}$ b.w. CP and doses were administered by oral gavage. 


\section{1, Biochemical analysis}

Blood samples were collected by cardiac puncture in EDTA tubes for the estimation of total protein [22] and acetylcholinestrase [23]. These tests were performed by using Avecon analyzer with Avecon commercial kits (www.aveconhealthcare.com) whereas DNA and RNA concentration were estimated using diphenyl assay [24] and Orcinol method [25].

\section{2, Histological examination}

For histopathological examination liver was removed from mice and transferred to fresh neutral buffered formalin and left in it for $24 \mathrm{hrs}$. The tissue was then removed carefully and washed with water for some times. Dehydration was done in the ascending grades of alcohol $(50 \%, 70 \%, 90 \%$ and absolute alcohol) for 30 minutes in each grade and transferred to xylene. The tissue was then embedded in paraffin wax and with the help of a rotary microtome and thin sections of 5 -- 6 microns were cut, spreaded, allowed to stand for a day and deparaffinated in xylene for 10 to 15 minutes. Then hydrated by passing through a descending alcohol series and then in distilled water. The sections were stained with Haris Haematoxylin solution and counter stained with alcoholic Eosin stain solution in ascending series of alcohol grade, mounted and observed under microscope.

\section{3, Statistical analysis}

The statistical calculations (mean, standard deviation, standard error, t-test) were done using Statistical Statsoft Inc., Release 5.0, Tulsa, OK, USA.

\subsection{Biochemical studies}

\section{Results}

In the present study the range of values of total protein $(6.35$ to $5.32 \mathrm{gm} / \mathrm{dl})$ and acetylcholinestrase (4.89 to $2.94 \mathrm{U} / \mathrm{L}$ ) and nucleic acid, DNA ( 1.23 to $0.82 \mu \mathrm{g} / \mathrm{ml})$ and RNA $(1.30$ to $1.46 \mu \mathrm{g} / \mathrm{ml})$ after the administration of different doses of Imidacloprid were observed (Table 1). Whereas in the untreated female mice and CP treated the total protein was $7.81 \mathrm{gm} / \mathrm{dl}$ and $4.39 \mathrm{gm} / \mathrm{dl}$ respectively. The results indicates that significant reduction in protein content with all doses of Imidacloprid $(\mathrm{P}<0.05 ; 0.01)$ and $\mathrm{CP}(\mathrm{P}<0.001)$. There is significant decrease in acetylcholinesterase $(\mathrm{P}<0.001)$ and DNA $(\mathrm{P}<0.05)$ whereas significant increase with RNA ( $P<0.01)$ was observed. However, an insignificant change in DNA and RNA at low dose of imidacloprid was observed.

\section{Histological analysis}

The histopathological examination of control mouse liver tissue (Fig. 2 a) revealed radially arranged hepatic cords around the central vein while the liver of the mice treated with Imidacloprid (Fig. 2 c-f) and Cyclophosphamide (Fig. 2 b) showed distorted central vein and dilated sinusoids between hepatocytes with a number of pycnotic nuclei along with distortion radial arrangement of hepatic cords. This could be due to morphological and chemical genotoxicity induced injury that was manifested itself in different ways.

The increase in extent of the damages with increase in doses of Imidacloprid was noticed in liver structural anatomy. The different extent of hepatocytes damage and blood sinusoids dilation, congestion within central veins and some sinusoids and necrotic debris with degenerated area and accumulation of RBC in portal vein were observed (Fig. 2 a-f). Degeneration and necrosis of hepatocytes appeared to be due to vascular changes induced particularly in the portal vessels (Fig. 2 a-f).

The CP treated tissue showed nuclear degeneration of hepatocyte cells as well as their necrosis to a great extent. After exposure, the hepatocytes exhibited clumped chromatin and irregular nuclear boundaries in addition to lesions that were observed to be occurred with approximately the same frequency (Fig. 2 b).

\section{Discussion}

The acute oral $\mathrm{LD}_{50}$ of IMC reported earlier in female Swiss albino mice was $150 \mathrm{mg} / \mathrm{kg}$ bw [26] whereas other studies reported $170 \mathrm{mg} / \mathrm{kg}$ [27] and $131 \mathrm{mg} / \mathrm{kg}$ [8]. In the present study exposure of Imidacloprid results in tiredness, frequent jumping in anxiety following reduction in movement and reduction in the intake of food was observed. Chao and Casida [28] have reported the accumulation of Imidacloprid or its metabolites in mouse brain following direct intra peritoneal administration. Toxicity signs of Imidacloprid were evident within 15 minutes following oral administration, might be due to rapid and complete absorption [29-31] and [6].

In present study mice treated with different doses of Imidacloprid exhibited a dose dependent decrease in actetylcholinestrase which is significant at all tested doses. There are no reports we came across in mice about AChE activity but reported in other systems as in a chronic study, the effect of Imidacloprid on the brain and serum AChE activity in rat was found significantly reducted at dose of $20 \mathrm{mg} / \mathrm{kg}$ bw per day, [32] Myzus 
persicae, [33] Chironomus riparius [34] and insignificant in chicken [35]. The reported pathological changes in brain and specific AChE inhibition revealed that multiple brain region abnormalities may be involved in changes of spontaneous locomotor activity. Neurobehavioral dysfunction at multiple anatomical areas in central nervous system was reported by Abou-donia et al [36] after exposure of sub-lethal dose of imidacloprid ( $327 \mathrm{mg} / \mathrm{kg} \mathrm{bw}$ ) during gestation of rat. Plasma AChE is synthesized in the liver and the decrease in plasma AChE activity may be related to observed changes in liver function, [11] in present study also severe signs of liver toxicity were observed for each dose tested. Some studies have shown that concentration of pesticides and metabolites in plasma and brain generally correlate with the severity of toxicity and symptoms of neurotoxicity which were found to increase with the pesticide concentration in brain [37-38]. Buckingham et al [39] reported that imidacloprid resulted in dose-dependent depolarizations of postsynaptic interneurones which may be the reason behind decrease in concentrations of AchE.

Our results about dose dependent decrease in total protein observed might be due to counter mechanism against different toxicity sign occurred due to exposure of Imidacloprid and are in agreement with reports available in other model organisms studied like in Channa punctatus [40] and Quails [41]. Rajput et al [42] reported that Imidacloprid caused up to $49 \%$ protein loss at lethal concentration (4 ppm) in liver in walking fish and at sub-lethal dose (2 ppm) caused 27\% protein loss. In contrary no changes in total protein reported in chicken [35] and rat [32] after Imidacloprid exposure. It is reported that organophosphorous pesticides decreased total serum proteins in treated animals [43-44, 23]. Physiological state and health of the animal may also related with the decrease in the protein content as pesticides may affect the gastrointestinal tract which results in decrease absorption and protein assimilation [45-46] Similar signs of toxicity were also reported earlier by Doull et al [47]. In this study following the dose of imidacloprid reduction in the food intake was observed which has also been considered as the reason of decrease in protein by many workers. LopezAntia et al [10] reported that starvation appears to be the reason for total protein reduction. It may be due to the increased protein catabolism because of starvation [45]. Avery et al [49] and Werner et al [50] reported that reduction in intake of food may be due to repellent effects of the pesticides whereas $\mathrm{Li}$ et al [51] reported that food intake reduction could be attributed to toxic effects of pesticides that made the exposed animal feels sickness and resulted in less food intake.

In present investigation on treatment of mice with Imidacloprid a dose dependent decrease for DNA but increase for RNA content was observed. Prasanna and Vardhani ${ }^{[52]}$ also studied effects of Imidacloprid (used $0.4 \mathrm{mg}-4 \mathrm{mg} / \mathrm{kg}$ bw) on DNA and RNA and reported significant decrease in both DNA and RNA in swiss albino mice. The inhibition in DNA and RNA observed may be due to genotoxic action of Imidacloprid which is reported by different researchers [53-56]. Genetic responses to oxidative stress are known to occur in bacteria, yeast, mammalian cell lines [57-58]. Several workers also considered DNA damage or impaired DNA synthesis as a reason for the decrease in the DNA content [59] whereas Awasthi et al [60] reported that decrease in DNA and RNA may be due to enzyme inhibition and apoptotic induction. RNA, DNA, protein and lipids were reported biological targets for the reactive oxygen species generated due to pesticide exposure [61$62]$.

Histopathological changes in animal tissues are powerful indicators of prior exposure to environment stresses and are net result of adverse biochemical and physiological changes in organisms [63]. The liver via the portal vein is the first organ exposed to drug and act as a huge complement of detoxification machinery system, ${ }^{[64]}$ Kammon et al [35] also reported that liver is the principal target organ in Imidacloprid toxicity.

In our study the most common findings in liver were fatty degenerative changes, necrosis of the parenchyma of hepatic lobule and degeneration of the hepatocytes and loss of normal architecture of hepatic cord and distortion of central vein. These results are in agreement with study conducted by Badgujar P et al [65] reporting no significant changes in the kidneys and lungs whereas in liver of mice in the test groups significant changes in morphology was reported. Being scarce reports available on mice but its toxicity has been reported in other model organisms like in mammalian system a dose of $45 \mathrm{mg} / \mathrm{kg}$ body weight caused significant changes in rat liver like dilation of central vein and blood sinusoids; wide spreads pycnotic nuclei and leucocytes infiltration in hepatic tissue [66]. The histopathology of Imidacloprid showing hemorrhages, congestion and mild dilation of hepatic sinusoids has been reported in animals like chicken,[35] Japanese quail [67].

The above reveals that oral administration of different doses of Imidacloprid induced significant reduction in total protein, DNA and acetylycholinestrase activity levels in all the experimental groups of mice. These changes reveal either a decreased catabolism of the biomolecules to meet the energy demand of animals under stress or their reduced synthesis due to impaired tissue function.

\section{Conclusion}

Imidacloprid has shown mild to severe toxic effects on both biochemical and histological parameters in female Swiss mice. India being agrarian state needs to take specific steps to educate farmers about pesticides 
ill effects and their judicious use so to limits its hazardous effect to the non-target species that are exposed to it directly or indirectly as taken along with food etc being residue in the agricultural products.

\section{Acknowledgements}

Financial assistance as Junior Research Fellowship, University Grant Commission-Rajiv Gandhi National Fellowship, UGC-MRP and for providing research facilities by Department of Zoology, Maharshi Dayanand University, Rohtak is highly acknowledged.

\section{References}

[1] N Mencke, P Jeschke, Therapy and prevention of parasitic insects in veterinary medicine using imidacloprid. Current Topics in Medicinal Chemistry, 2(7), 2002, 701-15.

[2] A Elbert, and H Overbeck, Imidacloprid: a novel systemic nitromethylene analogue insecticide for crop protection, In Proc. British Crop Prot Conf-Pests and Diseases, BCPC, Farnham, Surrey, UK, 1990, 21-28.

[3] A Elbert, B Becker, J Harwtig, C Erdelen, Imidacloprid: a new systemic insecticide. Pflanzenschutz-Nachrichten Bayer (German edition), 1991, 44, 113-136.

[4] A Elbert, M Haas, W Thielert, R Nauen, Applied aspects of neonicotinoid uses, In Proc. XVI Internat Plant Prot. Cong, Glasgow, UK, 2007, 3, 620-621.

[5] M Tomizawa, and J.E. Casida, Selective toxicity of neonicotinoids attributable to specificity of insect and mammalian nicotinic receptors, Annual review entomol, 48, 2003, 339-364.

[6] M Tomizawa, and J.E. Casida, Neonicotinoid insecticide toxicology: mechanisms of selective action, Annu. Rev. Pharmacol. Toxicol., 45, 2005, 247-268.

[7] R Wang, Z Wang, H Yang, Y Wang, and A Deng, Highly sensitive and specific detection of neonicotinoid insecticide imidacloprid in environmental and food samples by a polyclonal antibody-based enzyme-linked immunosorbent assay, Journal of the Science of Food and Agriculture, 92(6), 2012, 1253-1260.

[8] H Kidd, and D James, Agrochemicals Handbook. $3^{\text {rd }}$ Ed. England: Royal Society of Chemistry, 1994

[9] F Geiger, J Bengtsson, F Berendse, W.W. Weisser, M Emmerson, M.B. Morales, P Ceryngier, J Liira, T Tscharntke, C Winqvist, S Eggers, R Bommarco, T Part, V Bretagnolle, M Plantegenest, L.W. Clement, C Dennis, C.; Palmer, J.J. Onate, I Guerrero, V Hawro, T Aavik, C Thies, A Flohre, E.S. Hank, R.C. Fische, P.W. Goedhart, and P Inchausti, Persistent negative effects of pesticides on biodiversity and biological control potential on European farmland, Basic Appl. Ecol., 11, 2010, 97-105.

[10] A Lopez-Antia, M.E. Ortiz-Santaliestra, F Mougeot, and R Mateo, Experimental exposure of red-legged partridges (Alectoris rufa) to seeds coated with imidacloprid, thiram and difenoconazole, Ecotoxicology, 22, 2012, 125-138.

[11] Environmental Protection Agency, Imidacloprid risk characterization document dietary and drinking water exposure, health assessment section medical toxicology branch department of pesticide regulation California, 2006.

[12] I.W. Wu, A.L. Lin, and E.T. Cheng, Acute poisoning with nicotinoid insecticide imidacloprid in N-methyl pyrrlidone, Clinical Toxicology, 39 (6), 2001, 617-621.

[13] P Proenca, H Teixera, F Castaanheira, J Pinheiro, and P.V. Monsanto, Two fatal intoxication cases with imidacloprid: LC/MS analysis, Forensic Sci. Int., 153, 2005, 75-80.

[14] D David, I.A. George, and J.V Peter, Toxicology of the newer neonicotinoids insecticides: imidacloprid poisoning in a human, Clinical Toxicology, 45, 2007, 485-486.

[15] S Shadnia, and H.H. Moghaddam, Fatal intoxication with imidacloprid insecticide. Am. J. Emerg. Med., 26(5), 2008, 634 e1—634 e4.

[16] R Iyyadurai, I.A. George, and J.V. Peter, Imidacloprid Poisoning: Newer Insecticide and Fatal Toxicity, J. Med. Toxicol., 6, 2010, 77-78.

[17] N.M. Aly, Biochemical effects of certain pesticides on common carp (Cyprinus carpio L), J. Adv. Agric. Res., 10 (2), 2005a, 543556.

[18] K.S. El-Gendy, N.S. Ahmed, N.M. Aly, N Saber, and A.H. El-Sebae, Effect of some pesticides on the antioxidant enzymes and lipid peroxidation in carp tissues, J. Pest. Cont. Environ. Sci., 2, 1990, 21-27.

[19] K.S. El-Gendy, N.M. Aly, F.H. Mahmoud, A Kenawy, A.K. El-Sebae, The role of vitamin C as antioxidant in protection of oxidative stress induced by imidacloprid. Food chem. Toxicology, 48, 2010, 215-221.

[20] A.K. Salama, K.A. Osman, N.A. Saber, S.A. Soliman, Oxidative stress induced by different pesticides in the land snail, Helix aspersa. Pakistan journal Biological Science, 8, 2005, 92-96.

[21] Osman, K. A.; Aly, N. M.; Salama, A. K. The role of vitamin E and glutathione as antioxidant in the protection of oxidative stress induced by paraquat and diquat in female rats. Alex. Sci. Exch. 2000, 21, 247-259.

[22] Lowry, O. H.; Rosenbrough N. J.; Forr A.L.; Randal, R.J. Protein measurement with Folin Phenol Reagent. Journal Biol. Chem. $1995,193,265-275$.

[23] Zahran, M. M.; Abdel-Aziz, K. B.; Abdel-Raof, A.; Nahas, E. M. The effect of sub-acute doses of organophosphorus pesticide, Nuvacron, on the biochemical and cytogenetic parameters of mice and their embryos. Res. J. of Agri. and Bio. Sc. 2005, 1 (3), 277-283.

[24] Dische, Z. Some new characteristic colour tests for thymonucleic and microchemical method for determining the same in animal organs by means of these tests. Mikrochemie. $1930,8,4-32$.

[25] Lafarage, C.; Frayssinet, C. The reversibility of RNA and DNA synthesis induced by aflatoxin in rat liver. A tentative explanation for carcinogenic mechanism. Int. J. Cancer. 1970, 6, 74-83.

[26] Kataria, S. K., and Vinay, M. Software assisted determination of median lethal dose in acute studies of imidacloprid in Mice. In Reviewed proceedings of national seminar on Internet: Application in Research. Department of Zoology, M. D. University Rohtak, Harayana (India). March 23, 2011; 76-79.

[27] Thyssen, J.; Machemer, L. Imidacloprid: toxicology and metabolism. In Nicotinoid Insecticides and the Nicotinic Acetylcholine Receptor, Ed. I Yamamoto, JE Casida, Tokyo: Springer-Verlag, 1990, 213-22.

[28] Chao, S.L.; Casida, J.E. Interaction of imidacloprid metabolites and analogs with the nicotinic acetylcholine receptor of mouse brain in relation to toxicity. Pestic. Biochem. Physiol. 1997, 58, 77-88.

[29] Bai, D.; Lummis, S. C. R.; Leicht, W.; Breer, H.; Sattelle, D. B. Actions of imidacloprid and a related nitromethylene on cholinergic receptors of an identified insect motor neurone. Pestic. Sci. 1991, 33, 197-204. 
[30] Nauen, R.; Ebbinghaus-Kintscher, U.; Elbert, A.; Jeschke, P.; Tietjen, K. Acetylcholine receptors as sites for developing neonicotinoid insecticides. In Biochemical Sites of Insecticide Action and Resistance, Ed. Berlin, Heidelberg: Springer, 2001, 77105 .

[31] Solecki, R. Pesticide residues in food. Toxicological evaluations- imidacloprid. International programme on chemical safety/INCHEM/Joint FAO/WHO meeting on pesticide residues, JMPR. 2001, http://www.inchem.org/documents/ jmpr/jmpmono/2001pr07.htm.

[32] Bhardwaj, S.; Srivastava, M. K.; Kapoor, U.; Srivastava, L. P. A 90 days oral toxicity of imidacloprid in female rats: morphological, biochemical and histopathological evaluations. Food Chem. Toxicol. 2010, 48, 1185-1190.

[33] Zeng, C. X.; Wang, J. J. Time and dose effects of sublethal imidacloprid concentrations on acetylcholinesterase in Myzus persicae. Plant Protection. 2007, 33, 50-54.

[34] Azevedo-Pereira, H. M. V. S.; Lemos, M. F. L.; Soares, A. M. V. M. Effects of imidacloprid exposure on Chironomus riparius Meigen larvae: Linking acetylcholinesterase activity to behaviour. Ecotoxicol. Environ. Saf. 2011, 74, 1210-1215.

[35] Kammon, A. M.; Brar, R. S.; Banga, H. S.; Sodhi, S. Patho-biochemical studies on hepatotoxicity and nephrotoxicity on exposure to chlorpyrifos and imidacloprid in layer chickens. Veterinarski Arhiv. 2010, 80, 663-672.

[36] Abou-Donia, M. B.; Bullman, S. G.; Tu, T.; Khan, W.; Dechkovskaia, M.; Rahman, A. A. Imidacloprid induces neurobehaviorsl deficit and increase expression of glial fibrillary acidic protein in the motor cortex and hippocampus in offspring rats following in utero exposure. J. Toxicol. Environ. Health A. 2008, 71, 119-130.

[37] Sheets, L. P. An subchronic dietary neurotoxicity screening study with Technical Grade imidacloprid (NTN 33893 ) in Fischer-344 rats. Miles In (Mobay), Study No. 106356. DPR 1994; 51950-0471\# 2.

[38] Nagata, K.; Aistrup, G. L.; Song, J. H.; Narahashi, T. Subconductance-state currents generated by imidacloprid at the nicotinic acetylcholine receptor of PC 12 cells. Neuro Report. 1996, 7, 1025-1028.

[39] Buckingham, S. D.; Lapied, B.; Corronc, H. L.; Grolleau, F.; Sattelle, D. B. Imidacloprid actions on insect neuronal acetylcholine receptors. J. Exp. Biol. 1997, 200, 2685-2692.

[40] Priya, B. P.; Vijaya, R.; Avasn, M. Y. Acute toxicity effect of imidacloprid insecticide on serum biochemical parameters of fresh water teleost Channa punctatus. Int. J. Int sci. Inn. Tech. Sec. A, Jun. 2012, 1 (2), 18-22.

[41] Eman, G. E. Helal.; Samir, A. M. Z.; Nabil, F.; Mohammed, S. A. A.; Al-Shinway.; Amira, B. Abd-Al-Ghany. Ameliorative effect of glutathione supplementation against Imidacloprid intoxication in Japanese quails. Egyptian Journal of hospital medicine 2009 , $34,105-114$.

[42] Rajput, V.; Singh, S. K.; Kirti, A.; Abhishek. Comparative toxicity of Butachlor, Imidacloprid and Sodium fluoride on protein profile of the walking cat fish Clarias batrachus Journal of Applied Pharmaceutical Science 2012, 02 (06), $121-124$.

[43] Abd-El-Aziz, K.B. Pirmiphos-methyl as a mutagenic agent in mice and their embryos. Egypt. J. Appl. Sci. 1993, 8, 77-82.

[44] El-Fiky, S. A.; Abdel-Aziz, K. B.; Abd-El-Baset, S. A. Protective role of soybean against chromosomal and biochemical effects of carbaryal (sevin) in male mice. J. Egy. Sco. Toxicol. 1992, 9, 15-25.

[45] Zamanov, L.B. Change in the level of total 108 protein and fractions in the serum of sheep with aging. Sel. Skokhoz Biol. 1970, 5, 108-113.

[46] Hassan, A. B.; EI-Hady, K. A.; Sobhy, H. Effect of long-term administration of methomyl in rats. J. Egypt. Soc. Toxico. 1989, 4, 61-66.

[47] Doull, J.; Klassen, C. D.; Amdure, M. O. Cassaret and Doull's toxicology: The Basic Science of Poisons. ${ }^{\text {th }}$ Ed. Germany: Pergamoon Press 1991,401-400.

[48] Lewandowski A. H.; Campbell T. W.; Harrison G. J. Clinical chemistries. In Harrison GJ, Harrison LR (eds) Clinical avian medicine and surgery. W.B. Saunders Company, Philadelphia. 1986, 192-200.

[49] Avery, M.L.; Decker, D.G.; Fischer, D.L.; Stafford, T.R. Responses of captive blackbirds to a new insecticidal seed treatment. J. Wildl. Manag. 1993, 57, 652-656.

[50] Werner, S. J.; Linz, G. M.; Tupper, S. K.; Carlson, J. C. Laboratory efficacy of chemical repellents for reducing blackbird damage in rice and sunflower crops. J. Wildl. Manag. 2010, 74, 1400-1404.

[51] Li, J.; Bi, D.; Pan, S.; Zhang, Y. Effect of diet with thiram on liver antioxidant capacity and tibial dyschondroplasia in broilers. Br Poult Sci. 2007, 48, 724-728.

[52] Prasanna, M. N.; Vardhani, V. V. Effect of imidacloprid on the biochemical contents of kidneys in male Swiss albino mice. The Bioscan. 2013, 8 (3), 1069-1074.

[53] Feng, S.; Kong. Z; Wang, X; Peng, P; Zeng, E.Y. Assessing the genotoxicity of imidacloprid and RH-5849 in human peripheral blood lymphocytes in vitro with comet assay and cytogenetic tests. Ecotox. and Environ. Safety. 2005, 61 (2), $239-246$.

[54] Karabay, U. N.; Oguz, G. M. Cytogenetic and genotoxic effects of the insecticides, imidacloprid and methamidophos, Genet. Mol. Res. 2005, 4 (4), 653-662

[55] Demsia, G.; Vlastos, D.; Goumenou, M.; Matthopoulos, D.P. Assessment of the genotoxicity of imidacloprid and metalaxyl in cultured human lymphocytes and rat bone marrow. Mutat. Res. 2007, 634, 32-39.

[56] Costa, C.; Silvari, V.; Melchini, A.; Catania, S.; Heffron, J.J.; Trovato, A.; De Pasquale, R. (2009) Genotoxicity of imidacloprid in relation to metabolic activation and composition of the commercial product. Mutat. Res. 2009, 672, 40-44.

[57] Farr, S. B.; Kogoma, T. Oxidative stress response in Escherichia coli and Salmonella typhimurium. J. Bacteriol. 1991, 123, 570579 .

[58] Hidalgo, E.; Demple, B. Regulation of gene expression in Escherichia coli. In Lin EC, Luchi S(eds). Adaptive response to oxidative stress: the sox RS and oxy R regulons. RG Landes Co, Austin. 1995; 433-450.

[59] Blasiak, J.; Trzeciak, A.; Malecka--Panas, E.; Drejewoski, J.; Iwanienko, T.; Szumaiel, I.; Wojewodjka, M. DNA damage and repair in human loymphocytes and gastric mucosa cells exposed to chromium and curcumin. Teratog. Carcinog. Mutagen. 1990 , 19, 19-31.

[60] Awasthi, M.; Shah, P.; Dabale, M.; Gathia, P. Metabolic changes induced by organophosphates in the piscine organs. Environ. Res. 1984, 35, 320-325.

[61] Cabiscol, E.; Tamarit, J.; Ros, J. Oxidative stress in bacteria and protein damage by reactive oxygen species. Internatl. Microbiol. 2000, 3, 3-8.

[62] Lin-Quan, G.; Jun-Huan, Hu.; Jin-Cai, W.; Guo-Qing, Y.; Hainan, G. 2009. Insecticide-Induced Changes in Protein, RNA, and DNA Contents in Ovary and Fat Body of Female Nilaparvata lugens. Journal of Economic Entomology. 2009, 102 (4), 15061514.

[63] Hinton, D. E.; Lauren, J. C. Integrative histopathology approaches to detecting effects of environmental stress on fishes. Am. Fish. Soc. Symp. 1990, 8, 51- 66. 
[64] U.S.-E.P.A. 1986. Air quality criteria document for lead (Pb). Technical support document for Water quality-based toxics control. Washington DC: US Environmental Protection Agency, 1986, 4, 264-267.

[65] Badgujar, P. C.; Jain, S. K.; Singh, A.; Punia, J. S.; Gupta, R. P.; Chandratre G. A. Immunotoxic effects of imidacloprid following 28 days of oral exposure in BALB/c mice. Environ Toxicol and Pharmacol. 2013, 35, 408-418.

[66] Toor, H. K.; Sangha, G. K.; Khera, K. S. 2013. Imidacloprid induced histological and biochemical alterations in liver of female albino rats. Pesticide Biochemistry and Physiology. 2013, 105, 1-4.

[67] Omiama, S. E. 2004. Protective effect of vitamin C and glutathione against the histopathological changes induced by imidacloprid in the liver and testis of Japanese quail. Egypt. J. Hosp. Med. 2004, 16, 39-54.
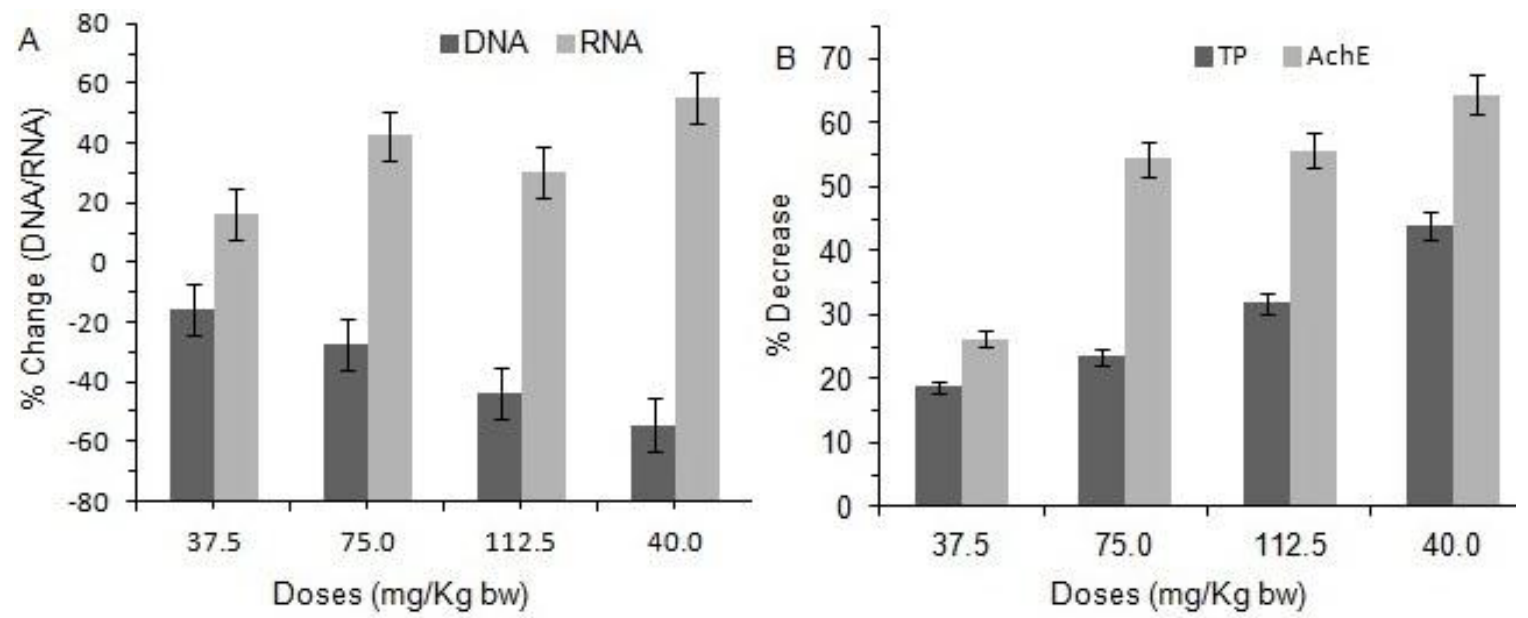

Fig. 1. The percent effect on different biochemical parameters in swiss albino female mice following Imidacloprid and Cyclophosphamide dose exposure. 

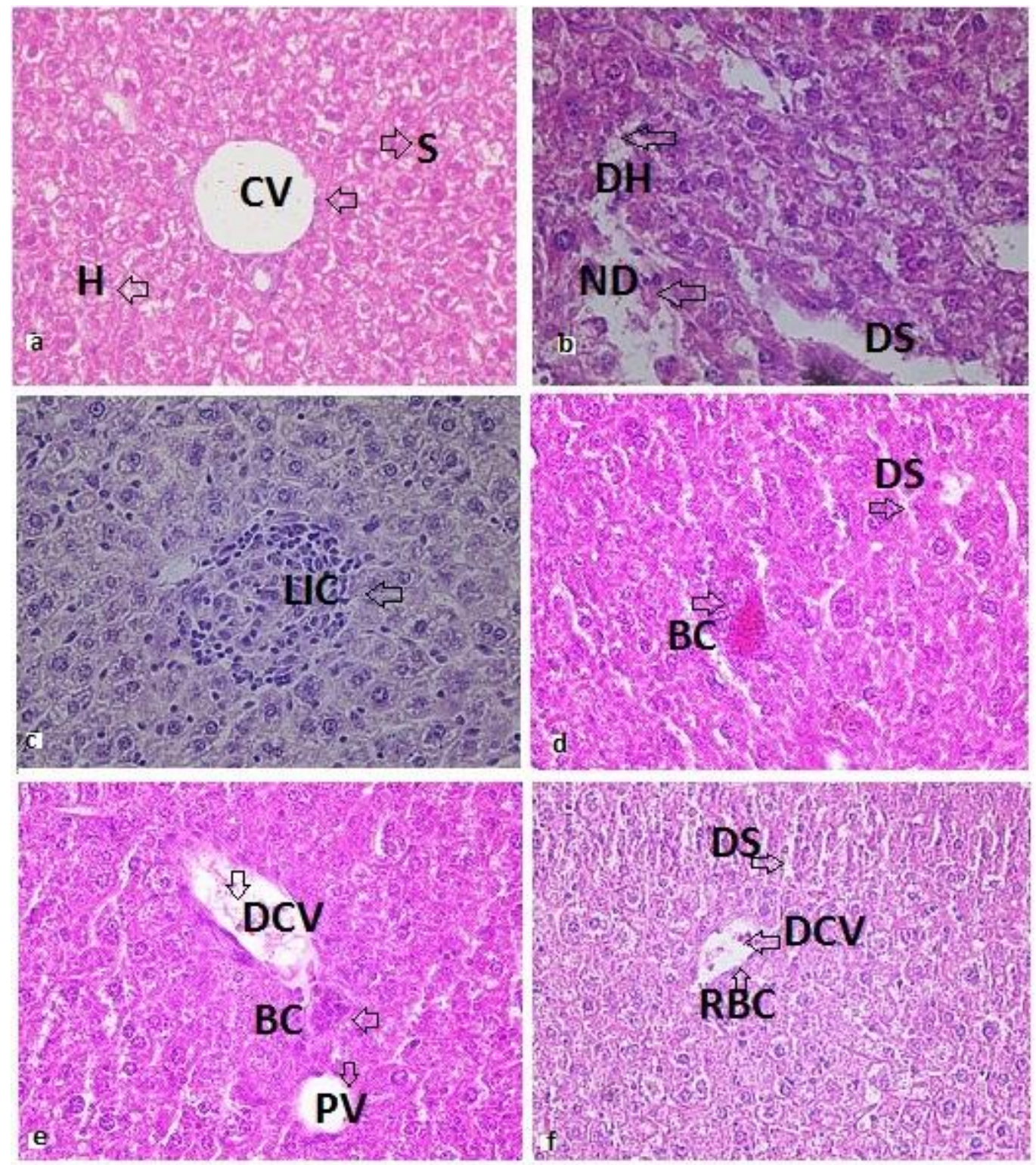

Fig. 2 The photomicrograph of mouse liver sections $(\mathrm{x} 400)$ from control mice, positive control and mice treated with Imidacloprid (A-F). The control showing normal structure, central vein $(\mathrm{CV})$ hepatocytes $(\mathrm{H})$ and sinusoids (S) (A). The liver treated with Cyclophosphamide (B) showing degeneration of hepatocytes (DH) with dilation of sinusoids (DS) and necrotic deberis (ND); with $37.5 \mathrm{mg} / \mathrm{kg}$ bw Imidacloprid (C) showing leucocytes cell infiltration; $75.5 \mathrm{mg} / \mathrm{kg}$ bw Imidacloprid (D) showing blood congestion (BC) and dilated sinousoids (DS) and with $112.5 \mathrm{mg} / \mathrm{kg}$ bw Imidacloprid (E-F) showing distorted central vein (DCV) and congestion with dilation of sinusoids, accumulation of RBC in vein central.

Table 1. Summary of Biochemical Changes in Female Mice after Different Doses of Imidacloprid and Cyclophosphamide (CP)

\begin{tabular}{|c|c|c|c|c|c|}
\hline \multirow[b]{2}{*}{ Biochemical Parameters } & \multirow[b]{2}{*}{$\begin{array}{c}\text { CP } \\
(40 \mathrm{mg} / \mathrm{kg} \mathrm{bw})\end{array}$} & \multirow[b]{2}{*}{$\begin{array}{l}\text { Distilled } \\
\text { Water }\end{array}$} & \multicolumn{3}{|c|}{ Imidacloprid } \\
\hline & & & $\begin{array}{l}37.50 \\
\mathrm{mg} / \mathrm{kg} \text { bw }\end{array}$ & $\begin{array}{l}75.00 \\
\mathrm{mg} / \mathrm{kg} \text { bw }\end{array}$ & $\begin{array}{l}112.50 \\
\mathrm{mg} / \mathrm{kg} \text { bw }\end{array}$ \\
\hline Total protein $(\mathrm{gm} / \mathrm{dl})$ & $4.39 \pm 0.17 * * *$ & $7.81 \pm 0.39$ & $6.35 \pm 0.14^{*}$ & $5.98 \pm 0.18^{*}$ & $5.32 \pm 0.01 * *$ \\
\hline ACHE U/L & $2.36 \pm 0.07 * * *$ & $6.64 \pm 0.24$ & $4.89 \pm 0.13 * *$ & $3.03 \pm 0.15^{* * * *}$ & $2.94 \pm 0.08 * * *$ \\
\hline DNA $(\mu \mathrm{g} / \mathrm{ml})$ & $0.67 \pm 0.04 * * *$ & $1.46 \pm 0.10$ & $1.23 \pm 0.20$ & $1.06 \pm 0.08 *$ & $0.82 \pm 0.014 *$ \\
\hline RNA (RNA) & $1.74 \pm 0.09 * *$ & $1.12 \pm 0.15$ & $1.30 \pm 0.07$ & $1.60 \pm 0.06 * *$ & $1.46 \pm 0.11 *$ \\
\hline
\end{tabular}

Note. $* * * \mathrm{P}<0.001, * * \mathrm{P}<0.01$ and $* \mathrm{P}<0.05$ 